\title{
Håndbold i kristendommens tegn
}

Af Keld Vestergaard Christensen

\section{Indledning}

Fredericia bliver i sportens verden fremhævet som en håndboldby. Det refererer til byens fortidige håndboldhistorie, hvor to lokale klubber fremstod som rivaler om at indløse billet til den fornemmeste række,

1. division for herrer.

Rivaliseringen fik den landsdækkende presse til at fokusere på håndboldspillet $\mathrm{i}$ byen. Byens håndboldhal blev døbt Fredericias fæstning. Det var stedet hvor FfFs hold (Fredericia forenede Fodboldklubber) forsvarede sig på strategi og let kavaleri, når KFUMs tunge skyts skød med kanoner. Røster fra dengang fortæller, at tilskuerne måtte beslutte sig for, om de ville gå ind $\mathrm{i}$ hallen med hænderne oppe - og klappe med - eller de ville gå med dem nede og intet foretage sig. Folk stod så tæt, at man ikke kunne ombestemme sig, når man først var kommet ind.

Det, at klubberne var rivaler, forstærkede klubtilhørsforholdene. Enten var man f'er eller også var man fum'er. Der var ikke noget med at skifte klub fra den ene dag til den anden, som man oplever det i dag. I stedet for blev man i sin klub og nøjedes med at drille de andre, hvad et eksempel kan illustrere. Efter sigende skulle FfFs spillere en gang imellem have hængt et skilt op uden for Glashallen, hvor der stod: »Adgang forbudt for »fumere «!

Det er ordet fumere, man skal hæfte sig ved. Jeg har studset over det ord nogle gange $\mathrm{i}$ forbindelse med mit arbejde med at skrive de fredericianske håndboldklubbers historie. Jeg kom i den forbindelse uvilkårligt til at stille det spørgsmål, om fumerne kun var et kælenavn for nogle håndboldspillere i KFUMs Boldklub, eller om ordet skulle tillægges en mere konkret betydning, det vil sige, at det samtidig dækkede over, at det $\mathrm{K}$ - som betyder kristendom - i mellemtiden var blev droppet $\mathrm{i}$ klubben, og at der derfor i bogstaveligste forstand kun var fumerne tilbage? Svaret er, at fumere i høj grad er et kælenavn for nogle håndboldspillere. Imidlertid kunne ordet lige så godt have haft den dobbeltbetydning, som jeg har antydet foroven.

I forbindelse med min undersøgelse af KFUMs Boldklub, fandt jeg desuden ud af, at det kristelige element har betydet noget forskelligt for håndboldspillet på forskellige tidspunkter i det historiske forløb. En forsmag på, hvad jeg hentyder til, kan være, at da håndboldspillet kom på Fredericia KFUMs program i 1926, forbød ledelsen håndboldspillerne at spille kampe mod ikke-kristelige foreninger. 40 år senere havde piben fået en anden lyd. Da skænkede lederne ikke kristendommen en tanke, når det gik løs på banen mod de såkaldt verdslige klubber.

Nærværende artikel beretter om kristendommens position i KFUMs Boldklub på forskellige tidspunkter i håndboldspillets 
forløb. Tanken er at give læseren et indblik $\mathrm{i}$, dels hvordan det har været at være håndboldspiller i en KFUM-klub på forskellige tidspunkter, dels hvordan konfrontationen mellem idræt og kristendom har formet sig - i det her tilfælde i forbindelse med håndboldspillet - i KFUMs Boldklub i Fredericia.

Artiklen begynder således med en indføring i, hvordan det overhovedet kom på tale at dyrke idræt i en kristelig forening.

\section{Fredericia KFUMs Idratsafdelings baggrund}

Fredericia KFUMs Idrætsafdelings opståen har rødder i den kirkelige splittelse, der opstod i midten af det forrige århundrede. Kristendommens indhold var til debat blandt kirkens folk. Et væsentligt spørgsmål var kirkens tilknytning til staten. En gruppe omkring N.F.S. Grundtvig ville sikre religionsfrihed. Det skulle ske ved at adskille stat og kirke, så statskirken ikke fremstod som den kristelige kirke. ${ }^{1}$

Omkring 1850 opstod den kirkelige retning Indre Mission. Indre Missions ledende skikkelse Vilhelm Beck ønskede også en adskillelse af stat og kirke, men argumentet var et andet. Kirken skulle gøres til et sted for de sande troende.

Selv om der var enighed mellem de to religiøse bevægelser om kirkens placering i forhold til staten, så fremstod de to bevægelser som diametrale modsætninger i religiøse spørgsmål. Synet på omvendelsen kan illustrere forholdet. Hvor grundtvigianere troede på menneskets mulighed for at blive omvendt efter døden, så dømte Indre Mission folk til helvede, hvis de ikke var blevet omvendt forinden. Blandt andet derfor kom Indre Mission til at fremstå som helvedesprædikanter i folkemunde. Grundt- vigianerne derimod legitimerede sig i form af Grundtvigs motto fra 1832, »Mennesket først, og kristen så«. ${ }^{2}$

Det var i høj grad gårdmændene, der tog grundtvigianismen til sig, mens et småborgerskab bestående af håndværkere, butiksindehavere og selvstændigt erhvervsdrivende sluttede sig til Indre Mission i stationsbyer og landsbyer.

Mod slutningen af det forrige århundrede begyndte industrialiseringen at slå igennem i Danmark. I forlængelse heraf voksede efterspørgslen på arbejdskraft hovedsageligt i København, men senere også i de små købstæder. Folk begyndte at flytte fra landet ind til byerne for at finde arbejde.

De voksende bybefolkninger fik Indre Missions opmærksomhed. Dels drejede det sig for bevægelsen om at fastholde de landlige tilflyttere i den kristne tro, dels udgjorde den voksende byungdom et religiøst medlemspotentiale. Grundtvigianerne derimod blev ude på landet og populært sagt, så stoppede grundtvigianismen ved byporten.

\section{Indre Mission danner Fredericia KFUM}

I bestræbelserne på at vinde byungdommen for den sande kristendom begyndte Indre Mission at danne KFUM-foreninger i byerne. Den første Kristelige Forening for Unge Mænd blev dannet i København i 1878. I 1888 blev der dannet en KFUMforening i Fredericia. Efterfølgende begyndte KFUK-foreninger at dukke op.

KFUM-foreningernes fokusering på den kristelige forkyndende vækkelse viste sig imidlertid hurtigt at være utilstrækkelig til at »indfange« de unge i byerne. Byerne bar præg af en religiøs frihedstrang omkring århundredeskiftet, der kom til udtryk ved 
en voksende interesse for anden kulturel udfoldelse end den religiøse. De antiklerikale tendenser manifesterede sig i den arbejderklasse, som opstod i forbindelse med det industrielle gennembrud, men desuden også i det etablerede borgerskab bestående af fabrikanter, finans- og embedsfolk.

\section{KFUM-foreninger opretter idraetsafdelinger}

Udviklingen førte til en intern strid i Indre Mission. En radikal fløj, med udgangspunkt i landsbyerne, stod stejlt på den forkyndende vækkelse som det eneste middel, mens en moderat fl $\varnothing \mathrm{j}$, der slog igennem i byerne, ville udvide bevægelsens gøremål bl.a. ved at dyrke sport og spejderliv. Det var ikke populært blandt de førstnævnte, som frygtede, at sportsdyrkelsen ville føre de unge væk fra Jesus. Byforeningerne valgte dog at se mulighederne i idrætten frem for at frygte for dens konsekvenser, og KFUM-foreningerne begyndte derfor at danne idrætsafdelinger og spejderafdelinger.

\section{Fredericia KFUMs Idrcetsafdeling opstår}

Selv om meningen med at oprette idrætsafdelinger således var religiøs begrundet, så er der ikke tvivl om, at mange KFUM'ere havde lyst til at prøve kræfter med idrætten.

I Fredericia havde KFUMs medlemmer således allerede i 1912 anmodet bestyrelsen om at få lov til at spille fodbold, men først i 1916 indvilgede ledelsen i at oprette en idrætsafdeling. Formålet med idrætten blev klart defineret: »Idrcetten skulle vare et middel til at udvikle et sundt legeme og desuden vare et middel $i$ kampen for sadelig renhed. $\ll^{3}$
Idrætten viste sig med det samme at være tillokkende for mange. Idrætsafdelingen kunne i løbet af tre år fremvise et medlemstal på 90. Det kristelige islæt holdt tilsyneladende ikke folk væk, for det var ikke kun ægte KFUM'ere, der meldte sig ind i idrætsafdelingen.

Fredericia KFUMs idrætsafdeling var en af landets første KFUM idrætsafdelinger, der blev dannet, og som en konsekvens heraf, var der kun få KFUM-foreninger at dyrke idræt med. Medlemmerne ville derfor gerne konkurrere mod de verdslige klubber i turneringer, som lå uden for KFUM-idrættens egne rækker. Det var imidlertid ikke KFUMs bestyrelses tanke med idrætsdyrkelsen, hvad der foranledigede bestyrelsen til at opstille et regelsæt med henblik på at kunne kontrollere idrætsdeltagelsen. På foreningens generalforsamling i 1919 blev det bestemt, at de som var medlemmer af idrætsafdelingen også skulle melde sig ind i KFUM (hovedafdelingen). Dernæst blev det besluttet at forbyde medlemmerne at deltage i KFUMs turneringer, hvis de samtidig deltog i turneringer uden for KFUMregi - med andre ord, hvis de var medlemmer af nogle verdslige klubber. ${ }^{4}$

Formålet med »den mission « var ikke til at tage fejl af. Der skulle renses ud i medlemsskaren, så kun de »rigtige« KFUMere blev tilbage. Og sådan kom det til at gå. KFUMs idrætsafdeling i Fredericia blev reduceret fra 90 til 60 medlemmer i løbet af tre år fra 1919 til 1922. ${ }^{5}$

\section{KFUMs Idroetsafdelings første formand}

Den ansvarshavende for reglerne var Fredericia KFUMs Idrætsafdelings første formand, arkitekt Budolf Billund. Billund var formand for idrætsafdelingen fra 1916 til 


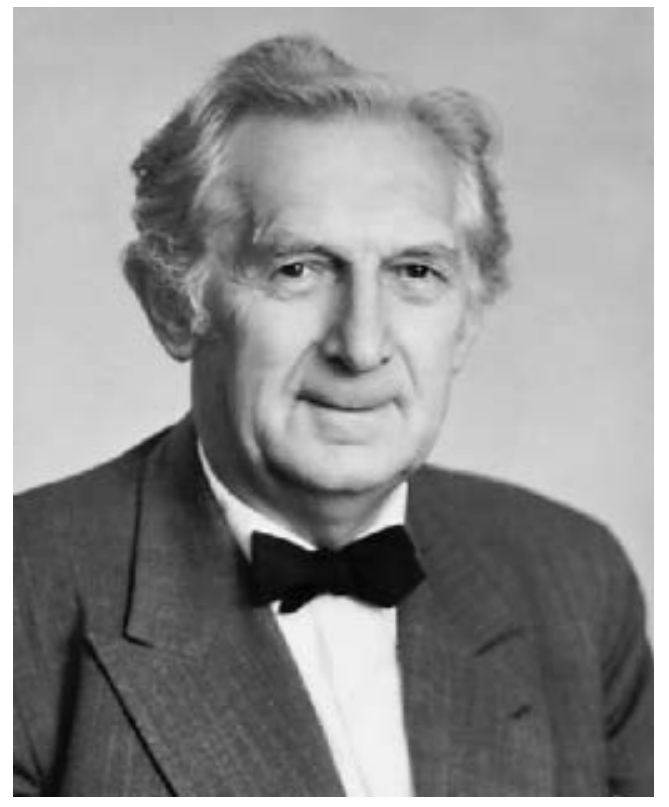

1922 og derefter menigt bestyrelsesmedlem indtil 1929. I samme periode var han medlem af KFUMs bestyrelse, hvad han fortsatte med at være til en gang i 1940'erne.

Billunds kærlighed til idrætten fornægtede sig ikke. Ved siden af sine gøremål i Fredericia var han initiativtager til KFUMs Idrætsforbund i Danmark, der blev dannet i 1918. Billund blev forbundets første formand, en post han bestred indtil 1923.

Lige så stor interesse Billund havde for idrætten, lige så stærk var han samtidig i ånden, hvad et eksempel kan vise. I forbindelse med hans fratrædelse som formand for KFUMs Idrætsforbund skrev forbundet om ham:

»Vi har $i$ ham haft en Formand med klar Forstaaelse af det centrale i KFUMs arbejde og vi ved, at det er hans storste $\emptyset$ nske, at Forbundets Ledelse altid ved siden af at arbejde for den idratslige fremgang må se klart paa, hvad der er vort egentlige Maal. $\ll^{6}$
Budolf Billund (1885-1964).

Budolf Billund var KFUMs Idratsafdelings åndelige leder helt op i 1930'erne. Billund var arkitekt, men var oprindelig uddannet murer. Som mange andre håndvarkere tilhørte Billund et småborgerskab i Fredericia, som var knyttet til Indre Mission. Det smittede af på hans arbejde $i$ KFUMs Idrcetsafdeling, hvor han fremstod som garanten for det kristelige element $i$ en periode afforeningens historie, hvor sekulariseringen trangte sig på.

\section{Idraet i kristelige rammer}

I en tid, hvor verdsliggørelsen slog igennem i byerne, fremstod Billund som garanten for, at det kristelige arbejde blev taget seriøst i KFUMs Idrætsafdeling. I 1925 kom det således til et forbud i foreningen mod at opføre komedier ved givne lejligheder. ${ }^{7}$ Der måtte ikke gøres grin med Gud.

Det sociale liv, der udfoldede sig ved festlige lejligheder, blev derfor koncentreret om kaffebord, andespil, lidt lotteri og ofte også en sketch for at få en smule at le af. Inden det blev alt for sjovt ved sådanne begivenheder, blev det hele dog afsluttet med et par alvorsord fra Bibelen, så medlemmerne havde den rette mine på, når de gik hjem.

Idrætsafdelingens klubaftener markerede i den forbindelse ingen undtagelse fra disse forhold snarere tværtimod. Indtil 1928 foregik klubaftenerne således udelukkende med oplæsning fra Bibelen. 


\section{Håndboldspillet kommer på idratsafdelingens program}

Idrættens rolle var således klart defineret på det tidspunkt, hvor foreningen begyndte at spille håndbold. Det skete i slutningen af 1926. Oprindeligt blev der spillet fodbold, kricket og dyrket fri idræt om sommeren, og desuden dyrket gymnastik om vinteren, men sidstnævnte disciplin var begyndt at kede medlemmerne. Forslaget om at afprøve håndboldspillet opstod i forlængelse af, at maskinkonstruktør Kaj Johnson fra idrætsafdelingens bestyrelse havde set en række kampe i forbindelse med KFUMs Idrætsforbunds gymnastikstævne i Odense i februar 1926. På et bestyrelsesmøde derefter præsenterede Johnson bestyrelsen for spillet, og det blev besluttet at forhøre sig om interessen blandt medlemmerne. Spillerne var positive over for ideen, og så kom håndboldspillet til at afløse gymnastik som vinteridræt. Håndboldspillet blev den følgende vinter afprøvet i slutningen af gymnastiklektionerne, og allerede i løbet af 1928-1929 havde håndboldspillet udkonkurreret gymnastikken, så sidstnævnte aktivitet helt måtte ophøre for en periode.

Medlemmerne havde umiddelbart bedre forudsætninger for at komme til at spille håndboldkampe, end tilfældet havde været med fodbold. Det skyldtes, at idrætsafdelingen i 1929 reviderede sine love. Formålet med idrætten blev:

»Idratsafdelingen skal arbejde for tilvejebringelsen af de bedst mulige Forhold for udøvelsen af Gymnastik, Fodbold, fri Idrat, Kricket og Haandbold inden for KFUM i Fredericia. ${ }^{8}$

Håndboldspillet var dog et forholdsvis nyt spil på det tidspunkt, ${ }^{9}$ hvad der betød, at en organisering af spillet ikke havde fundet sted, hverken på landsplan eller på regionalt niveau. Imidlertid var KFUM-idrætten den, der var længst fremme med at organisere håndboldspillet.

På den baggrund kom idrætsafdelingens håndboldspillere allerede i kamp i 1929 i forbindelse med en sydjysk turnering for KFUM-hold. Året efter deltog foreningen med et herrehold i de første landsmesterskaber for KFUM-håndboldhold, der foregik i Odense, og allerede året efter igen arrangerede man så selv landsmesterskaberne i håndbold. Det hele syntes nærmest at gå for stærkt. I hvert fald havde man ikke nået at anskaffe sig en håndbold, da forbundets håndboldstævne blev henlagt til Fredericia, så kampene måtte i stedet for spilles med en fodbold. ${ }^{10}$

\section{KFUMs Idratsafdeling bryder med KFUM-idratten}

Håndboldspillerne undgik ikke at blive berørt af regulativerne fra 1919, der som nævnt forbød medlemmerne at spille med i KFUMs turneringer, hvis de deltog $i$ andre turneringer uden for KFUM-regi. I 1928 blev foreningens håndboldtræner, købmand Viggo Rasmussen, indberettet af nogle juniormedlemmer, fordi han samtidig spillede fodbold i Fredericia Boldklub. Det foranledigede Viggo Rasmussen til at ville stoppe sin trænergerning. Bestyrelsen opfordrede imidlertid Rasmussen til at fortsætte uanset sine aktiviteter i en anden klub. ${ }^{11}$ Bestyrelsens opfordring til Rasmussen markerede et holdningsskifte blandt idrætsafdelingens ledere i forhold til tidligere tiders syn på idrætsdeltagelsen. Der var opstået et $\varnothing$ nske om at bryde med den isolering af KFUM-idrætten, der hidtil havde været tale om. Bestyrelsens holdning var identisk med det synspunkt, som 
et KFUM-medlem var fremkommet med på et tidligere tidspunkt: »Kan en ung Mand da ikke vare en lige saa god KFU$M$ 'er, fordi han spiller Fodbold eller dyrker anden Idrat $i$ en verdslig Klub. " ${ }^{12}$

Det kunne man ikke være, da Billund var formand, men den tid var passé. $\mathrm{Nu}$ hed formanden i stedet for Alfred Hansen.

Maskinsmed Alfred Hansen var idrættens mand, hvad idrætsafdelingens prioriteringer fremover kom til at bære præg af. Hansen afviklede begge de regler, som hidtil havde fastholdt idrætten i KFUMrammer. Viggo Rasmussens sag vidner herom, ligesom idrætsafdelingen ved at tilmelde et seniorhold til JBUs turnering i 1932 brød med forbudet om at blande sig med de verdslige klubber. ${ }^{13}$ Tilmeldingen af et hold til de verdslige turneringer fik nærmest revolutionerende karakter. Hansen nøjedes nemlig ikke med at tilmelde et hold til JBUs turnering i 1932. Idrætsafdelingens bestyrelse opfordrede desuden andre KFUM-foreninger i Danmark til at følge trop. Prikken over i'et var dernæst et forslag til idrætsforbundet, der i al sin enkelthed gik ud på, at de skulle nedlægge KFUM-turneringen. ${ }^{14}$

Idrætsafdelingens bestyrelse gik dermed på kompromis med foreningens egne love fra 1929 og »pustede ild « til den debat, der kom til optage KFUM-idrætten i 1930'erne, - hvordan skulle man forholde sig til medlemmernes idrætsdeltagelse uden for egne rækker?

\section{Håndboldspillets svare betingelser}

Uanfægtet af diskussionerne om idrættens placering, så blev der spillet håndbold i byens Eksercerhus i løbet af 1930'erne, hvor ca. 30 håndboldspillere fra KFUMs Idræts- afdeling spillede håndbold en gang om ugen, fordelt på et til to herrehold og et juniorhold.

Der var dog mange vanskeligheder med at få spillet etableret, hvad der var flere årsager til. For det første var det dyrt for idrætsafdelingen at leje kasernesalen. I november 1933 mente et bestyrelsesmedlem derfor, at man skulle nedlægge håndboldspillet for at spare penge. Det kunne der dog ikke blive tale om, for Alfred Hansen ville bevare spillet, koste hvad det ville. ${ }^{15}$

For det andet manglede idrætslederne indsigt i spillet. Det kom til udtryk ved forskellige lejligheder, bl.a. når idrætsafdelingen var vært for KFUMs landsmesterskaber. I 1934 havde man planlagt en alle mod alle turnering. Undervejs i stævnet fandt lederne ud af, at man ikke kunne nå at spille kampene. Så blev holdene omdelt i puljer, uden at man af den grund fik indhentet det tabte. ${ }^{16}$

Når det overhovedet kom på tale at vælge Fredericia KFUM som arrangør, hang det sammen med, at spillet kunne foregå i byens kasernesal. Den var væsentlig større end de gymnastiksale, som man ellers brugte til at spille i. Både i længden og i bredden var der mere plads i Eksercerhuset, hvad der gjorde det muligt at afvikle et »rigtigt « håndboldspil med syv mand på hvert hold. Der var dog lige det problem, at salen $i$ den ene side blev udgjort af murhjørner og jerngevækster. Det generede imidlertid ikke spillerne, som gerne risikerede nogle skrammer for at kunne spille på så stor en bane som mulig. Imidlertid var det idrætsafdelingens bestyrelse, der bestemte, når Fredericia arrangerede landsmesterskaberne i håndbold, så derfor blev der kridtet en linie op, for som klubbens sekretær Johs. Nielsen understregede: »Jeg lagger ikke Navn til Blodpletter paa omtalte Faremomenter. Der skal nok komme 
Røde Kors tilstede. Men - der er altsaa en Granse ... «17

Imidlertid nøjedes Nielsen ikke med at kridte én enkelt linje op foran jerngevæksterne i forbindelse med stævnet i 1934. I stedet for blev der kridtet en hel bane op, så der blev taget et godt stykke af banens længde og bredde. Det skete til stor fortrydelse for spillerne, og med udsigt til en gentagelse året efter fik det den københavnske håndboldleder Olaf Hasfeldt til at gøre opmærksom på:

»Jeg ser, at der skal spilles paa opkridtet Bane uden Sidevag, formodentlig i Eksercerhuset som sidste Aar. Det er komplet Haablфst. Banen bliver i saa Tilfalde, saa lille og smal, at der ikke kan spilles Haandbold paa den. Der er ingen Plads til de 14 Spillere. Resultatet bliver som sidste Aar Klumpspil, Slagsmaal, elendigt Tempo ... Det kan vare meget fornøjeligt som Nytaarssp $\phi$, men Holdbold bliver det ikke. Haandbold er Sammenspil, Fart, Elegance... Altsaa bort med Sidelinierne, spil helt ud til ribberne og lav Spillepladsen saa lang som den overhovedet kan blive ${ }^{18}$

Johs. Nielsen var uforståelig overfor kritikken og svarede igen: »Er Eksercerhuset haablфst, saa er det haabløst. Punktum. Det kan altsaa ikke blive brugbart ved at lagge 2 á $3 m$ til Spillepladsens Bredde og nogle faa m. til Laengden. « ${ }^{19}$

Men det var akkurat, hvad der skulle til for at afvikle et fornuftigt håndboldspil. Som Hasfeldt replicerede: »Enhver der har Begreb om Haandbold ved, at 2 á $3 m$ til Bredden og nogle $m$. i Langden netop, modsat Deres Opfattelse (Nielsens) har megen Betydning. ${ }^{20}$

Det var ikke kun ved det årlige landsstævne, at idrætsledernes mangelfulde ind- sigt i håndboldspillet kom til udtryk. Det voldte desuden kvaler at lære medlemmerne spillet. Det første håndboldspil var kraftbetonet, og i KFUMs Idrætsafdeling udviklede det sig ofte voldsomt i forbindelse med træningen. Det foranledigede en række bestyrelsesmedlemmer til at ville nedlægge spillet med den begrundelse, at det var en skamplet på foreningen. ${ }^{21}$ Selv foreningens egen juniortræner Th. Krabbe var i 1935 indstillet på at stoppe med håndbold:

»Spillerne mangler forståelse for spillet, og de tror, at de kan gøre, hvad de vil på banen. De er for små til at magte spillet og er desuden ikke for godt bekendt med reglerne ${ }^{22}$

Krabbes erfaringer stod i skærende kontrast til datidens syn på spillet, hvad håndboldteoretikeren Poul Jørgensens opfattelse af spillet kan bekræfte:

»En svaghed ved spillet: Det er for let laert, man når for hurtigt så stor fardighed i teknik og taktik, at man vanskeligt kan arbejde videre frem. Spillet indeholder ikke de rige udviklingsmuligheder som de store spil kricket, fodbold og hockey, så håndbold er og må betragtes som et overgangsspil og forberedelsesspil til de store spil. «23

Jørgensens betragtninger om spillet passer således også bedre med de erfaringer, som KFUKs gymnastikpiger gjorde med håndboldspillet. KFUKs piger kunne nemlig ikke få nogen træner, da de begyndte at spille håndbold i 1934. I stedet for købte spillerne en bog, hvor reglerne stod i, og lod det være op til Søster Jensen at læse om spillet og instruere veninderne bagefter. ${ }^{24}$

Håndboldspillet overlevede de mange aflivningsforsøg, og da KFUM-idrætten 
blev »frigivet « i 1930'erne, opstod muligheden for at blande sig med de verdslige klubber. Det kom så til at foregå udendørs, hvor håndboldspillet slog igennem som et festspil. I 1937 blev sportsfesten i Fredericia markeret med en opvisningskamp i håndbold mellem KFUMs herrer $\mathrm{og}$ en flok fodboldspillere fra Fredericia Boldklub. Den kamp vandt FBs fodboldspillere til stor ærgrelse for KFUMs Idrætsafdelings bestyrelse, som noterede: »Sportsfesten forl $\phi b$ nogenlunde, men vi fik os en stor skuffelse $i$ håndbold, idet vi blev slået af $F B . \ll^{25}$

De første seks-syv års træning havde tilsyneladende ikke hjulpet synderligt på håndboldspillernes sportslige formåen.

\section{Fredericia KFUM placerer en missionar i idrotsafdelingen}

Den oprindelige idé, at det var KFUM som fuldt og helt skulle tage ansvaret for idrætsarbejdet, ${ }^{26}$ blev efterhånden taget af bordet. KFUMs Idrætsforbund opfordrede i stedet til, at et bedre samarbejde måtte finde sted mellem de lokale KFUM-foreninger og deres respektive idrætsafdelinger. Det var idrætsforbundets $\emptyset$ nske og vel ikke mindst KFUMs ønske, at de lokale KFUM-foreninger mødte den $\varnothing$ gede idrætsdeltagelse med en $\emptyset$ get fokusering på det kristelige arbejde. Som det blev udtrykt:

»Jo mere vi leder de unge til at gå op $i$ deres sport, og det bliver jo resultatet af at vare med i de almindelige turneringer, idet der stilles større idratslige krav og lagges beslag på megen mere fritid til traning og kampe, des stcerkere må det kristelige arbejde blandt de unge drives frem af lederne. ${ }^{27}$
Selv om KFUMs idrætsledere i Fredericia førte an i den løsrivelsesproces, der fandt sted, så var der ikke tale om en afvisning af kristendommen. Det kom bl.a. til udtryk, da idrætsafdelingen efterhånden fik svært ved at få sine medlemmer til at møde frem til hovedafdelingens bibeltimer. I stedet for tilbød idrætsafdelingens bestyrelse KFUMs ledelse, at de selv kunne afholde bibeltimer for medlemmerne. ${ }^{28}$ Den løsning var dog ikke i overensstemmelse med filosofien om at møde den $\varnothing$ gede idrætsdeltagelse med en øget fokusering på kristendommen, så i første omgang valgte KFUMs bestyrelse at satse på et tættere samarbejde.

Bestyrelsen tog en række initiativer, der skulle sikre det. For bedre at kunne styre de fredericianske »rebeller «, besluttede KFUMs bestyrelse i Fredericia, at deres sekretær Johs. Nielsen skulle være bestyrelsesmedlem $\mathrm{i}$ alle mindre afdelinger inden for KFUM-foreningen. Det kom til at markere en opprioritering af det kristelige arbejde, for Johs. Nielsen var en stærk person på det religiøse felt, hvad et udsagn fra et KFUMmedlem kan bekræfte: »Johs. Nielsen maler et billede af Kristus så starkt, så det for mange bliver et valg. $\ll^{29}$

Der blev taget fat på forholdet vedrørende de idrætsmedlemmer, der var medlemmer i idrætsafdelingen men ikke stod indskrevet i KFUM. På et bestyrelsesmøde i idrætsafdelingen stillede Nielsen et forslag om, at disse medlemmer blev smidt ud. Forslaget foreligger ganske vist ikke med den konkrete ordlyd, men ud fra den debat, som fandt sted på mødet, tyder meget på, at det var det, Nielsen $\varnothing$ nskede, at der skulle ske. ${ }^{30}$ Forslaget fik imidlertid ikke tilslutning nok, og i stedet for måtte Nielsen nøjes med at henstille til, at de fire første klubaftener blev brugt på idrætslederskole. ${ }^{31}$ Det krævede ændringer, fordi der siden Hansens tiltræden som formand blev spillet bob 


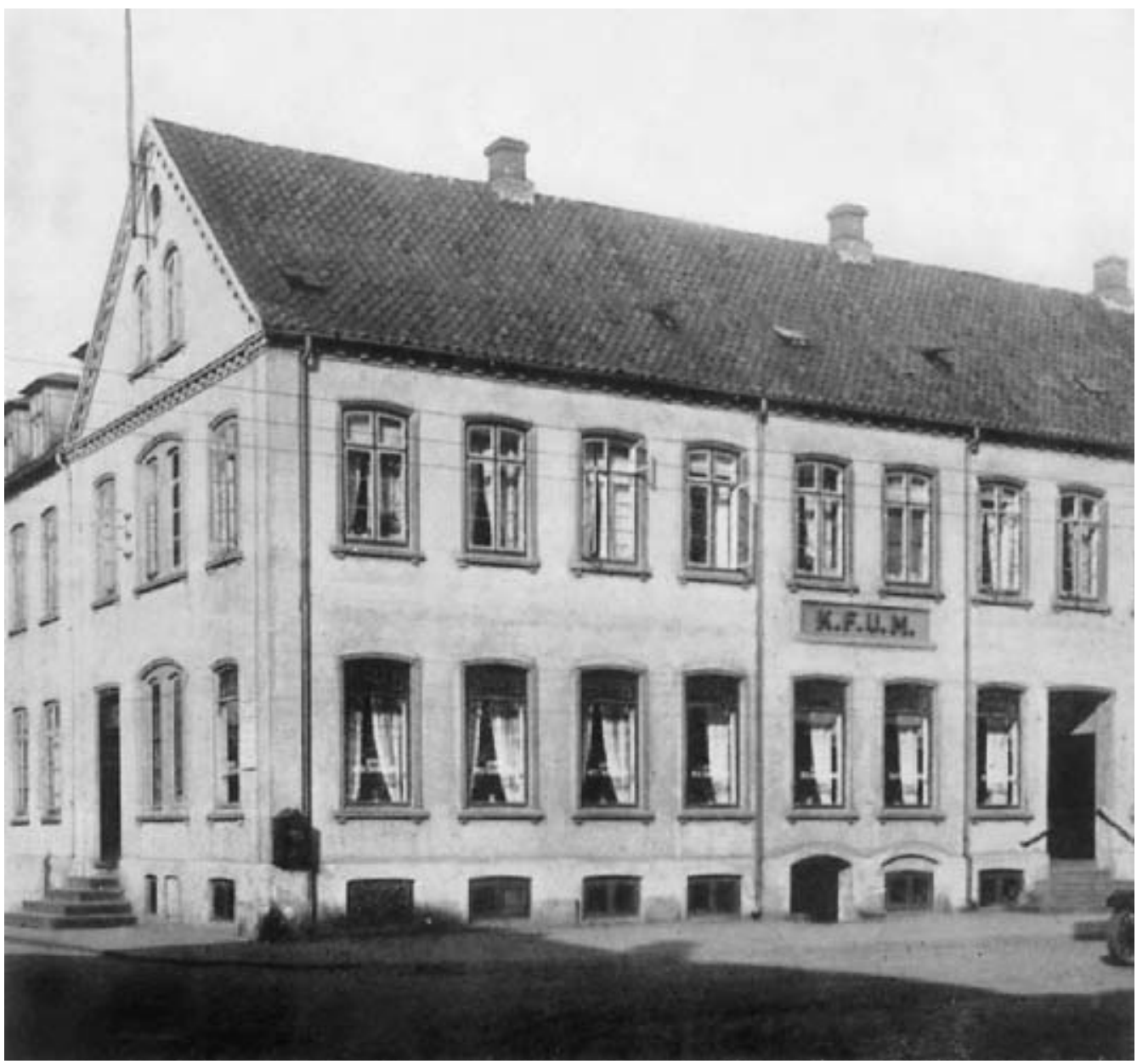

Fredericia KFUMs bygning på hjørnet af Gothersgade og Fynsgade i Fredericia.

KFUMs håndboldspillere fik sig et tilholdssted, da hovedafdelingen $i 1937$ indrettede en idratsstue til medlemmerne. Det skete som et led $i$ at knytte idratsafdelingens medlemmer toettere til sig. KFUMs ledere frygtede, at det religiфse arbejde blev svigtet af idrotslederne og håbede at løse problemerne ved at invitere idratsfolket hjem i eget hus.

og bordtennis ved disse lejligheder. Det skete på bekostning af fordybelse i Bibelen med den begrundelse, at man ønskede at gøre klubaftenerne mere hyggelige. ${ }^{32}$

I 1936 blev KFUMs bibeltimer så alligevel inddelt $\mathrm{i}$ grupper. Idrætsafdelingen fik $\mathrm{i}$ den forbindelse deres egen gruppe at se til, men det skete med Nielsen som observatør. Effekten af Johs. Nielsens arbejde udeblev ifølge KFUMs ledelse ikke. I forbindelse med foreningens jubilæum i 1938 noterede et medlem fra bestyrelsen:

»Jeg tror med sandhed, at man kan sige, at vi andeligt talt har gjort gode fremskridt. Vores bibeltimer er igen godt besøgt. Tak Nielsen, fordi du holdt ud $i$ modgang. ${ }^{33}$ 


\section{Idrat og kristendom sidestilles}

Denne udtalelse må dog siges at være en sandhed med modifikationer. I hvert fald var det ikke idrætsafdelingens ledere, som var begyndt at møde op til KFUMs bibeltimer. Tilslutningen til KFUMs bibeltimer havde i mellemtiden nået et foreløbigt lavpunkt blandt idrætslederne. I 1937 deltog kun to ledere fra idrætsafdelingens bestyrelse i hovedafdelingens bibeltimer, uanset det faktum at de kunne gå direkte fra bestyrelsesmøde i idrætsafdelingen til KFUMs bibeltimer i lokalet ved siden af. ${ }^{34}$ Selv om Johs. Nielsen sørgede for, at de kristelige budskaber blev formidlet, så kunne han ikke tæmme de kræfter, der var blevet sluppet løs i idrætsafdelingen. Der blev derfor heller ikke tale om at underordne idrætten det kristelige arbejde, som det havde været tilfældet i 1920'erne. Man nærmede sig i stedet for en sidestilling af idræt og kristendom. Det kom til udtryk som en adskillelse af de to fænomener, hvad to eksempler kan give besked om.

I 1937 blev det besluttet, at bestyrelsesmøderne fremover skulle inddeles, så den første halvdel drejede sig om idræt og den anden halvdel om åndelige ting. Dernæst blev det bestemt, at idrætsafdelingens klubaftener skulle være et forum, hvor åndelige og idrætslige temaer blev taget op på skift. ${ }^{35}$

\section{Kristendommens status bliver truet $i$ idratsafdelingen}

Krigsårene kom til at ændre betingelserne for det kristelige arbejde. Der kom masser af medlemmer til KFUM i Fredericia. De nye medlemmer søgte imidlertid alle til idrætsafdelingen. Det civile KFUM ople- vede til gengæld en stor tilbagegang i antallet af medlemmer. ${ }^{36}$

Medlemstilgangen betød, at idrætsafdelingen fik behov for flere ledere til at varetage opgaver på det idrætslige felt. En bestyrelse på 5 til 7 medlemmer kunne ikke længere magte opgaverne. Der begyndte derfor at komme nye ledere/trænere til i KFUMs Idrætsafdeling, som primært kom for idrættens skyld og ikke nødvendigvis havde rødder i et kristeligt miljø.

Udviklingen påvirkede miljøet i foreningen. Det kunne KFUMs ledere registrere i forbindelse med foreningens nytårsfest. Nytårsfesten var et højdepunkt $\mathrm{i}$ foreningen, og der var tradition for et arrangement, som blev indledt og afsluttet med bibelske budskaber. Mellem de forkyndende ord blev der spillet musik, drukket kaffe, hvorefter medlemmerne som regel satte kolorit på begivenhederne ved at opføre en sketch.

Tiden var imidlertid ved at løbe fra denne festform. I hvert fald hvis man skulle tro medlemmerne. I forlængelse af nytårsfesten i 1941 mente håndboldholdets træner H. Dellgren, at nytårsfesten var blevet alt for kedelig. Han opfordrede til, at der blev dannet et festudvalg, hvor ikke kun lederne, men også spillerne blev repræsenteret. ${ }^{37}$

Helt så bramfri var KFUKs håndboldspillere ikke. De lod dog deres synspunkter komme til udtryk, når chancen bød sig ved festlige lejligheder. Komedier var som bekendt forbudt, men medlemmerne måtte gerne opføre sketcher. Det gjorde damerne bl.a. i 1944, hvor en passus havde følgende ordlyd: »Tror De på Gud? « - hvortil der blev svaret - »ja det gør jeg da, nogen gange $i$ hvert fald. ${ }^{38}$

Festformen i KFUM- og K-regi skal sammenholdes med tilsvarende fester i andre foreninger dengang. Et eksempel kan være Fredericia Gymnastikforenings måde 
at feste på. I FG begyndte festerne med en komedie. Bagefter var der bal, hvor der oven i købet var offentlig adgang. Ved disse lejligheder sørgede bestyrelsen for at indhente polititilladelse, så ballet kunne blive ved til klokken fire om morgenen.

Det kan være, at det var disse fester, som KFUMs håndboldtræner Dellgren hentydede til, når han mente, at KFUMs fester var for kedelige.

Idrætsafdelingen holdt i løbet af krigsårene to klubaftener om ugen, hvor den ene blev afviklet som en bibeltime, mens den anden blev brugt på anden underholdning, bl.a. bordtennis. Selv om idrætsafdelingens ledelse fortsatte med at prædike kristendom, så blev det kristelige arbejde adskilt fra idrætten og forskellige andre sociale arrangementer. Hvor medlemmerne i 1930'erne blev konfronteret med kristendommen, fordi idrætslige og kristelige emner blev diskuteret i samme forum, så betød den permanente opdeling, at medlemmerne reelt kunne undgå at beskæftige sig med religiøse emner ved at undlade at $m \varnothing-$ de op til de klubaftener, hvor emnerne var af religiøs karakter.

Selv om medlemmerne begyndte at komme for idrættens skyld, så havde idrætsafdelingens bestyrelsesmedlemmer fortsat rod i et KFUM-miljø. De ledere blev der brug for til at bevare kristendommens status i løbet af 1940'erne, fordi presset på kristendommens position ikke kun kom til at udgå fra egne medlemmer, men efterhånden også fra omverdenen.

Et eksempel på det forhold kan være en invitation, som KFUMs Boldklub modtog i $1946 .{ }^{39}$ Klubbens håndboldherrer blev inviteret til at deltage $\mathrm{i}$ et stævne i Herning $\mathrm{i}$ påsken. Der skulle spilles håndbold langfredag, vel vidende at det var forbudt for KFUM-hold at udøve idræt på helligdage. Alligevel blev KFUMs Boldklub inviteret.
KFUMs Idrætsafdelings bestyrelse sørgede dog for at sende afbud på håndboldspillernes vegne. ${ }^{40}$

\section{Ildsjael får håndboldspillet etableret}

Håndboldspillet havde få ildsjæle til at føre spillet frem i foreningsregi. KFUMs Boldklub fik fat på én i skikkelse af lagerist Arne Rasmussen. Rasmussen var en anerkendt håndboldtræner i Fredericia, fordi han førte FGs damer til et jysk mesterskab i 1939. I forlængelse heraf opfordrede han KFUMs Idrætsafdelings bestyrelse til, at de skulle prøve at gøre noget ved håndboldspillet. Det gjorde de så ved at ansætte Rasmussen, som efterfølgende blev træner for KFUMs herrer.

Rasmussen var knap nok blevet ansat som træner, før han foreslog, at foreningen meldte fra til KFUMs turneringer, for som han udtrykte det: »Man var jo ikke interesseret $i$ at vinde dem alligevel. $" 41$

I stedet for at spille med i KFUMs turneringer, skulle man ifølge Rasmussen vælge at deltage i JHFs turneringer. Førstnævnte idé blev der ikke noget ud af, fordi Rasmussen ikke have mandat til at bestemme det, men det andet ønske gik i opfyldelse. I 1940 blev KFUMs håndboldherrer tilmeldt Jysk Håndbold Forbunds turneringer.

Det krævede en $\emptyset$ get træningsindsats. Desværre for Rasmussen og co., så beslaglagde tyskerne byens kaserne, og foreningen måtte flytte håndboldspillet ind $\mathrm{i}$ gymnastiksalene, så længe krigen varede. Det gav mindre plads, men det foranledigede ikke Rasmussen til at slække på træningen, hvad et af hans træningspas kan illustrere: 
"I vore ugentlige time starter vi med lфbeфvelser banen rundt, Vending til højre og venstre, Løb paa stedet, Baglans løb, Opsamling af Bold ved Gulvet under løb saavel ved venstre som højre side. Indфvelse af forskellige Stødkast, Underarmskast. 2 Haands fra Brystet osv. Endvidere фver vi Skud paa Maal, saavel Stфdkast som Svingkast og Bagudkast.«2

Rasmussen var dog ikke tilfreds med træningsfaciliteterne. - »Vi kan ikke under de nuvarende Forhold give vore Spillere den traning, som er nødvendig. Vi kan kun spille med 5 mand på hvert hold, 3 forwards, 1 Forsvarer og 1 Maalvogter. « ${ }^{43}$

På trods af dårlige vilkår udeblev resultaterne ikke. I 1944 rykkede KFUMs herrehold op i en regional 1. divisionsrække i udendørs håndbold, og så skulle foreningen pludselig til at tage entre til kampene. Klubben var dog knap nok klar til at spille divisionshåndbold. Det krævede nemlig, at der var net i målene. ${ }^{44} \mathrm{I}$ al hast fik man fremskaffet dem.

Idrætsafdelingens bestyrelse var begejstret både for håndboldspillernes præstationer, men også for selve spillet. Om spillerne hed det: "Havde fodboldspillerne vist samme interesse for at trane som håndboldspillerne, så var de ikke rykket $u d .{ }^{45} \mathrm{Om}$ selve håndboldspillet mente bestyrelsen: »Spillet er underholdende for publikum, og kampene kan afvikles samtidig med at andre forteelser foregik. $\ll^{46}$

At der reelt var tale om én mands værk, kan følgende udsagn bekræfte. I forbindelse med den medlemstilgang, som foreningen oplevede i de første krigsår, kunne bestyrelsen ikke finde ledere nok til at tage sig af alt arbejdet. Man besluttede derfor i 1943, at overlade håndboldafdelingen til Arne Rasmussen. Helt gratis slap man ik- ke, idet Arne Rasmussen skulle have 10 kroner om måneden for at tage sig af håndboldafdelingen. ${ }^{47}$ Dermed blev han foreningens første lønnede træner.

Rasmussen fremstod som KFUMs håndboldafdelings fremtrædende leder og træner helt frem til 1950. På det tidspunkt blev KFUM og KFUK lagt sammen og KFUMs Boldklub kunne for første gang udbyde håndboldspillet til begge $\mathrm{k} \emptyset \mathrm{n}$.

\section{Idratsafdelingen afviser at samarbejde med KFUM}

Sålænge at kristendom og idræt forblev adskilt i KFUMs Boldklub, var det svært at formidle kristendommens budskaber til medlemmerne. Det var også den erkendelse, som man nåede frem til i KFUM-kredse:

»Kirken må ikke isolere sig - heller ikke fra Idrattens Omraade, thi en Isolering vil vare yderst farlig, fordi den fremmer Scekulariseringstendensen, vor Tids Hovedonde. $\aleph^{48}$

Holdningen var ikke til at tage fejl af. Handling var påkrævet, hvis ikke sekulariseringen skulle afideologisere KFUMs idrætsafdelinger. ${ }^{49}$ Som udgangspunkt var oplægget til en fremtidig kristendomspolitik en tilbagevenden til fortidens forening af kristendom og idræt i idrætsafdelingerne. Ildsjæle var påkrævet til dette formål. Til alt held for kristendommens forkæmpere i Fredericia havde KFUMs Boldklub en sådan leder i skikkelse af folkeskolelærer, Johs. Rasmussen. Johs. Rasmussen var formand for KFUMs Boldklub fra 1947 til 1956, og med ham ved roret blev der gjort fors $\emptyset \mathrm{g}$ på at styrke samarbejdet med KFUM om det kristelige arbejde.

Det første af en række initiativer gik ud 
på at samarbejde med hovedafdelingens UA'ere og YA'ere om de såkaldte drengemøder, der var et forum for kristendomsforkyndelse. ${ }^{50}$ Disse møder havde boldklubben selv taget sig af $\mathrm{i}$ årene forud, men det havde fungeret dårligt, hvad et eksempel skal illustrere. I 1952 fik ungdomsudvalgets formand Harald Hansen »skældud « af Johs. Rasmussen: »For meget arbejde bliver ikke lavet, der savnes en fast hånd om drengem $\phi$ derne. Det er ungdomsudvalgets opgave. $" 51$ I forbindelse med samarbejdet om drengearbejdet forpligtede Rasmussen sig overfor hovedafdelingen til at deltage med en leder fra boldklubbens bestyrelse hver gang. ${ }^{52}$

Johs. Rasmussen opfordrede også idrætsafdelingens ledere til at begynde at deltage noget oftere i KFUMs HA-møder, dog uden nogen effekt, for et par år senere var han ude i samme ærinde igen. Med Rasmussens egne ord var der opstået et alvorligt behov for, at idrætslederne mødte op til HA-møderne. ${ }^{53}$

Der blev ydermere taget initiativ til at starte en bibelkreds op for boldklubbens medlemmer. Det var bankbogholder Iver Ravn og ekviperingshandler Harry Andersen, som var repræsenteret i både hovedafdelingens og boldklubbens bestyrelse, der fik idéen. Bibelkredsen blev imidlertid en fiasko, idet alt for få mødte frem. ${ }^{54}$

Fra KFUMs side var det kutyme at invitere boldklubbens ledere til de forskellige arrangementer, og KFUMs årlige lederkursus var ingen undtagelse. Dette kursus var idrætslederne imidlertid begyndt at svigte. Udsigten til at det skulle ske igen, fik I.K. Østergaard, der repræsenterede KFUM i boldklubbens bestyrelse, til på det kraftigste at anbefale idrætslederne at møde op. ${ }^{55}$ Manden talte imidlertid for døve ører. Mange idrætsledere $\varnothing$ nskede slet ikke at have noget med KFUM at gøre. I 1955 kom det derfor til et decideret brud mellem hovedafdelingen og boldklubben. Ungdomstrænerne sagde nemlig nej til et ønske fra hovedafdelingens side om at deltage med deres ungdomsmedlemmer i boldklubbens sommerlejr ved Daneborg. ${ }^{56}$

\section{Kristendommen får nyt indhold i KFUMs Boldklub}

Johs. Rasmussen kunne således ved selvsyn konstatere, at mange af de ny ledere i boldklubben kom for idrættens skyld og var uinteresseret i foreningens kristelige arbejde. Det var et forhold, som Rasmussen stod magtesløs overfor uanset hans position som formand og hans bestræbelser på at bevare et samarbejde med det civile KFUM.

Formanden havde samtidig erfaret, at udviklingen også var slået igennem blandt de aktive:

"Hvor er det svaert; man taler til medlemmerne ved moder og andagter - der er stilhed. Man regner med, at det hoenger ved-og så...Jeg tror, vi ledere mere og mere skal tale på tomandshånd, når det gaelder kristendom. Det er afgjort det, der mangler, og derfor står det slфjt til kristeligt. «"

Rasmussen mente, at det ikke nyttede at prædike Guds forordning og bud. Udfordringen bestod $\mathrm{i}$ at udskifte de religiøse budskaber og nøjes med at prædike moral og god opførsel. Det er også sådan, at Waldemar Hansen fortæller, at det blev gjort i 1950'erne: ${ }^{58}$

»Jeg husker en situation som seniorspiller, hvor jeg efter et brandt skud udbrod Satans osse. Rasmussen, som altid overvarede vores kampe på Norremarken, 


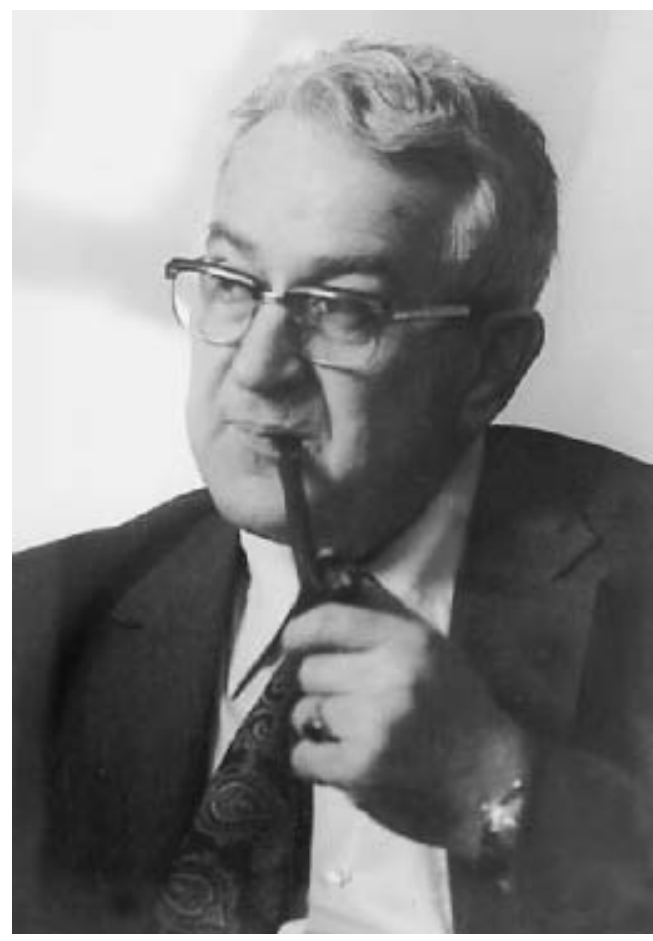

kaldte mig hen og sagde - "Synes du, det lod specielt godt, de ord du brugte? $\ll^{59}$

Johs. Rasmussen blev den centrale figur i KFUMs Boldklub i 1950'erne, når det drejede sig om at formidle kristendom, og som daværende bestyrelsesmedlem Dahlhus fortæller: „Det var ham (underforstået Rasmussen), og kun ham, der forstod at tale til medlemmerne om kristendommen på en god måde. ${ }^{60}$

Kristendomsformidlingen blev kædet sammen med sociale aktiviteter og kom til at foregå dels i KFUM-parken, hvor Rasmussen afsluttede seniorernes »torsdagsmøder « med andagt, dels i boldklubbens »idrætsstue « i hovedafdelingens lokaler, hvor Rasmussen som ungdomsformand fra 1956 til 1962 samlede klubbens unge. Disse klubaftener var belærende,
Johs. Rasmussen (1916-1974).

Johs. Rasmussen var formand for KFUMs Boldklub fra 1947 till956. Efterfølgende fungerede han som ungdomsformand frem til 1962. Det var i Johs. Rasmussens formandsperiode, at der skete et brud med kristendommen i KFUMs Boldklub. Detforegik med Rasmussens egen velsignelse, idet han erkendte, at det ikke nyttede at pradike Guds forordning og bud til medlemmerne. Det førte til, at Rasmussen gennemforte en ny kristendomspolitik $i$ KFUMs Boldklub, der bestod i at prædike moral og god opførsel på bekostning af Guds forordning og bud.

kammeratlige og forkyndende på én og samme tid. Klubaftenerne blev indledt og afsluttet med ord fra Bibelen, men arrangementerne havde også et skær af sport over sig, bl.a. i form af instruktioner i fodboldeller håndboldregler. Desuden blev der vist film og sunget sange, og det var populært blandt medlemmerne at spille Hvem, Hvad, Hvor.

Gyda Pedersen husker udmærket disse klubaftener fra sin tid som håndboldspiller i KFUMs Boldklub: „Vi blev altid linet op, og så skulle vi sidde på rakker og synge. Ofte var det 'Altid frejdig, når du går' «. ${ }^{6 l}$

På trods af Rasmussens indsats, så frygtede KFUMs ledere, at kristendommen ikke nåede ud til medlemmerne. Med Dahlhus ord så var der en angst for, at boldklubben glemte andagten efter træning, og at de kristelige budskaber ikke blev formidlet til 
medlemmerne. Den angst var ikke ubegrundet, fordi boldklubbens måde at rekruttere ledere på til det idrætslige arbejde ikke tog noget hensyn til det kristelige element. Boldklubbens bestyrelse sorterede således trænerne efter deres interesse for fodbold og håndbold og ikke efter deres kristne tilhørsforhold. ${ }^{62}$ Det skete ud fra den filosofi, at man ikke kunne pådutte lederne at være bekendende kristne, hvis de ikke var det. ${ }^{63}$

Boldklubbens bestyrelse tilbød i stedet for, at KFUMs ledelse kunne sende repræsentanter til at formidle kristendommen. ${ }^{64}$ Det gjorde KFUMs ledelse imidlertid ikke, dels i erkendelse af at kun Johs. Rasmussen var i stand til at få medlemmernes opmærksomhed, dels som en konsekvens af, at de ikke var særlig velkomne blandt idrætsmedlemmerne, der ikke $\emptyset n-$ skede at beskæftige sig med den form for kristendomsformidling, som det civile KFUM praktiserede.

\section{Håndboldspillet får et gennembrud}

På trods af en øget fokusering på turneringshåndbold i JHF regi, så plejede håndboldspillerne deres KFUM-relationer i begyndelsen af 1950'erne. Det skete ved at arrangere private kampe mod KFUMklubber i oplandet. Om sommeren kørte en flok herrer og damer på cykel til Erritsø og Pjedsted for at spille håndbold med KFUM-kammerater. Der var ingen omklædningsrum, så spillerne klædte om bag ved kirkediget eller bag et træ. Efter kampene blev der serveret kaffe i missionshuset, og var spillerne heldige så havde damerne bagt kage.

Om vinteren spillede et par seniorhold turneringshåndbold i JHF-regi. Det foregik udenbys, fordi der ikke var en håndboldhal i Fredericia. I 1952 lykkedes det imidlertid for KFUMs håndboldafdeling at leje byens Møbelhal af Dansk Købestævne for en enkelt dag. Så blev der arrangeret de første bymesterskaber i håndbold. Over 100 håndboldspillere fra klubber, skoler og firmaer i byen deltog i stævnet. ${ }^{65}$

Håndboldspillet var på det tidspunkt ved at få et nationalt gennembrud. Godt 70.000 håndboldspillere blev til ca. 120.000 på landsplan på fem år fra 1948 til 1953. ${ }^{66}$ Håndboldspillet blev på kort tid Danmarks næstmest populære idræt. Det var mange voksne, men endnu flere børn og unge, der fik lyst til at spille håndbold.

Interessen for spillet smittede efterfølgende af på KFUMs håndboldafdeling. 30 spillere blev til ca. 200 på fem år. ${ }^{67}$

De mange håndboldspillere blev proppet ind $\mathrm{i}$ byens gymnastiksale om vinteren og desuden på kasernen. I gymnastiksalene var det umuligt at spille »rigtig « håndbold, og i takt med at der blev turneringer at deltage $\mathrm{i}$, hvor der stod point på spil, voksede behovet for bedre forhold.

I samarbejde med naboklubben $\mathrm{FfF}^{68}$ forsøgte KFUMs Boldklub at lægge pres på byens politikere, $\mathrm{i}$ forbindelse med at Dansk Købestævne opførte en hal i Fredericia i 1954. En håndboldleder skrev:

»Byen har fors $\phi m t$ udviklingen ved ikke at have skabt et samarbejde med Dansk Købestavne, der nu for anden gang bygger en hal, hvis dimensioner muligg $\phi r$ indend $\phi r s$ sport ... til argrelse for byens håndboldspillere, der er henvist til at leje sig ind ved militaret for 22 ore $i$ minuttet... Jeg henstiller til valgerne til det kommende byrådsvalg, at stemme på aspiranter, der vil stotte byens sportsungdom. ${ }^{69}$ 
I første omgang lykkedes det kun at få en aftale istand med Dansk Købestævne om at bruge deres gamle hal »Møbelhallen « fredag efter klokken 22.00 og så desuden om søndagen.

Håndboldspillerne fik dermed en hjemmebane, som tilmed var ubehagelig for udeholdene. Det mente pressen i hvert fald, som forud for en af KFUMs kampe rapporterede: »Geesteholdene vil vare lidt forsigtige paa det haarde Stengulv. ${ }^{70}$

Hjemmebanefordel eller ej - så kneb det med resultaterne. I Jyske Sport kunne man i 1956 læse, at KFUMs jyllandseriehold for femte gang spillede om oprykning til den jyske mesterrække, og at holdet for femte gang kun var nogle få mål fra det forjættede land..$^{71}$

For at lave reklame for håndboldspillet arrangerede KFUMs Boldklub stævner på søndage, hvor ungdommen kunne boltre sig det meste af dagen - dog ikke i kirketiden fra 10.00-12.00. Om eftermiddagen havde håndboldafdelingens ledere fået håndboldspillets koryfæer til at komme og give opvisning i spillet. 1. divisionsholdene fra AGF og Svendborg gæstede bl.a. Møbelhallen og gav KFUMs spillere en håndboldlektion. Hvis overmagten så ud til at blive for stor, som da HG stillede op »med selveste Knud Lundberg på holdet ${ }^{72}{ }^{72}$ sa slog man sig sammen med bysbørnene fra FfF og lavede et byhold.

Samlet var initiativerne med til at sikre, at den lokale ungdom fortsat strømmede til håndbold. I 1956 blev KFUMs Boldklub nødsaget til at dele klubben op i en seniorafdeling og en ungdomsafdeling med hver deres ledere.

Medlemstilgangen tvang i sidste ende så kommunen til at løse håndboldfolkets problemer med at finde plads. I 1957 bevilgede de $25.000 \mathrm{kr}$. til at gøre Købestævnets Glashal klar til håndbold. Dermed fik
KFUMs håndboldafdeling den plads de behøvede til at huse de 150 drenge og piger, som dukkede op for at spille håndbold i efteråret $1957 .^{73}$

\section{Kirketidsreglen kommer under pres}

Efterhånden som de mange håndbold- og fodboldspillere blev organiseret i turneringer, blev der flere kampe at spille i weekenderne. Det foregik i JHF-regi om vinteren og i KFUM-regi om sommeren. Kirketidsreglen kom i fokus, da det blev et problem at finde tid nok til at afvikle kampene. Det blev et spørgsmål, om højmessetiden søndag fra kl. 10.00 til 12.00 skulle inddrages til idræt eller fortsat helligholdes. En debat slog igennem i KFUM-idrættens egne rækker i slutningen af 1950'erne. En KFUMer mente at, »kirken siger, søndagen er Herrens dag, menfolket siger søndagen er vor egen «.$^{74}$

Når det kom på tale at omgå kirketidsreglen, var det bl.a. fordi, at stadig færre medlemmer gik i kirke. Det blev derfor relevant at stille det spørgsmål, at hvis man alligevel ikke gik i kirke om søndagen, hvorfor kunne man så ikke lige så godt bruge tiden på idræt, når det oven i købet interesserede en?

I et flertal af KFUM idrætsafdelinger på landet stod man fast på, at højmessetiden var »fredhellig«, men i de voksende idrætsforeninger i byerne, var der brug for at inddrage kirketiden til idræt - således også i KFUMs Boldklub i Fredericia.

For at tilfredsstille flest mulige besluttede KFUMs Idrætsforbund, at der kunne gives dispensation for kirketidsreglen i særlige tilfælde, også selv om regulativerne var klart imod. I KFUMs Idrætsforbunds paragraf 25 stk. 1 stod der: 
„På søn- og helligdage er idrcetsudøvelse, træning, konkurrencer og kampe, såvel af turneringsmassig som privat karakter, ikke tilladt afdelinger under Forbundet eller de enkelte medlemmer $i$ Forbundet $i$ højmessetiden kl. 10.00$12.00 . \ll^{75}$

Havde forbundet forestillet sig, at deres beslutning om at give dispensation i særlige tilfælde ville lægge låg på debatten, skulle de blive klogere. Diskussionerne fortsatte ufortrødent i begyndelsen af 1960'erne. Et medlem følte i den forbindelse, at kristendommens position blev truet $\mathrm{i}$ en grad, at han ønskede at gøre opmærksom på, at »vi skal ikke skjule en andagt eller camouflere en bibeltime - vi arbejder $i$ et lovligt arinde. $\ll^{76}$

Ret hurtigt fortrød forbundet sin beslutning og trak muligheden for at få dispensation tilbage. KFUMs Boldklub modtog en skrivelse fra forbundet, hvor der stod, at der ikke længere ville blive givet dispensation for aktiviteter i højmessetiden. ${ }^{77}$

Sålænge der kunne dispenseres fra kirketidsreglen, blev det gjort i KFUMs Boldklub. Bagefter måtte boldklubben kompensere for »tidstabet « ved at lave friluftsgudstjenester. De blev ved særlige lejligheder flyttet ud på idrætspladsen og/eller ind i idrætshallen. Så kunne aktiviteterne foregå helt til kl. 10.00 og sættes i gang igen præcis kl. 12.00 og således reducere tidstabet mest muligt.

\section{Håndboldafdelingen tager kristendommen af bordet}

Medlemstilgangen til KFUMs Boldklub i 1950'erne skabte et behov for at adskille håndbold- og fodboldspillerne. Det skete i 1962, hvor håndbold- og fodboldfolket blev opdelt i to afdelinger med hver deres ledelse. Tre år senere var tiden kommet til at gøre adskillelsen mere permanent. KFUMs håndboldafdeling blev selvstændig med egen ledelse og fik samtidig ansvaret for sin egen $\varnothing$ konomi.

En hovedbestyrelse blev nedsat til at varetage håndbold- og fodboldafdelingens interesser $\mathrm{i}$ forskellige sammenhænge. Klubbens love og vedtægter blev ændret, så de passede på nutiden.

Det fik konsekvenser for kristendommens position. Klubbens formål blev »at samle sportsinteresserede medlemmer og blandt disse fremme interessen for idrat. Det skal dog ske i nøje overensstemmelse med KFUMs and. $"{ }^{78}$

Det civile KFUM fik én repræsentant $\mathrm{i}$ hovedbestyrelsen, men ingen i håndboldafdelingen. Det var skæbnesvangert, fordi ingen af de »nye « håndboldledere havde rødder i et KFUM-miljø. Således heller ikke håndboldafdelingens formand fra 1967 til 1988, lærer Peter Egon Jensen, som aldrig havde været medlem af nogen kristelig forening, før han kom til KFUMs Boldklub. ${ }^{79}$ Da Johs. Rasmussen samtidig blev knyttet til fodboldafdelingen, var der ingen i håndboldafdelingen, der kunne formidle kristendommen til medlemmerne.

For håndboldspillerne blev der tale om at få et andet udbytte af medlemskabet $\mathrm{i}$ 1960'erne. Hvad der havde med kristendom at gøre kom til at virke forstyrrende på håndboldspillet, hvad kirketidsreglen er et eksempel på. Men også andagterne blev nu til irritationsmomenter for spillerne ved kampe og stævner. Hvor medlemmerne i 1950'erne havde fnist og smågrinet, når idrætsaktiviteterne blev stoppet for at give plads for en andagt, så blev der reageret anderledes kraftigt i 1960'erne. Som daværende leder Erling Tinghus fortæller: 
»Når vi havde turneringskampe eller stcevner (i KFUM-regi), blev der indlagt en andagt. Det var pinligt for os ledere. Spillerne forduftede fra hallen. Vi andre var tvunget til at blive. Vi kunne ikke vare andet bekendt. Heldigvis stoppede vi med andagter i forbindelse med turneringshåndbold. $\ll^{80}$

Rasmussens »fravær fik desuden indflydelse på det sociale liv i håndboldafdelingen. Foreningens klubaftener med Johs. Rasmussen som en central figur faldt bort. I stedet for kom håndboldspillernes sociale liv til at udfolde sig i Glashallen. I Glashallen kunne spillerne stort set opholde sig fra morgen til aften, enten på banen, bag ved målene eller i det tilstødende cafeteria. Håndboldafdelingen følte sig hjemme dér og overlod gradvist KFUM-parken til fodboldafdelingen.

Andre måder at være sammen på blev dominerende. Juleafslutning, fastelavnsog afslutningsfester blev de nye trends, hvis de da ikke allerede var det i forvejen.

KFUMs håndboldafdelings sociale liv kom på den måde til at forme sig som en tro kopi af naboklubben FfFs sociale liv. Det specielle ved at være KFUM'er var forbi. Klubben mindede på tærsklen til 1970'erne på alle måder om en verdslig klub. Kun navnet adskilte foreningen fra andre klubber.

\section{Sportificeringen vandt over kristendommen ${ }^{81}$}

Der var derfor hverken behov eller forståelse for Bibelen, når det gik løs på banen i 1960'erne. Håndboldfolkets egne ledere sørgede for, at håndboldspillet kom i centrum. Fokuseringen på præstation, konkurrence og resultater blev entydig blandt håndboldlederne, hvad et eksempel kan illustrere.

I 1962 forsøgte håndboldlederne at melde fra til KFUM- og Ks turneringer, fordi kampene var uden sportslig værdi. ${ }^{82}$ Boldklubbens hovedbestyrelse fastholdt imidlertid, at håndboldafdelingen fortsat skulle deltage af ideologiske grunde.

Der opstod i begyndelsen af 1960'erne en rivalisering mellem KFUM og FfFs håndboldafdelinger, som blev væsentligt forstærket af, at holdene kom til at spille i den samme række. I 1962 tabte KFUM det indbyrdes opgør i mesterrækken med 2917 og var pludselig kun de næstbedste i byen. Det havde man ikke prøvet før. Værre var det, at over 1000 tilskuere var mødt frem i Glashallen for at følge slaget. Nederlaget sved og førte til selvransagelse blandt lederne. Bestyrelsen erkendte, at det havde været en dårlig besparelse at slække på udgifterne til en håndboldtræner, men det var sket, fordi man havde vurderet, at håndboldspillerne tilsyneladende havde tabt pusten, fordi det ikke var lykkedes at rykke op gennem flere år. ${ }^{83}$

Efterfølgende blev Ejner Jessen ansat som træner til $75 \mathrm{kr}$. pr. træningsaften, uden at der kom bedre resultater ud af det. Året efter lykkedes det så alligevel for KFUMs herrer at rykke op og lederne åndede lettet op: »Der havde ganske enkelt ikke voret andet at gore end at rykke op, for at afstanden ikke skulle blive for stor til de fremadstormende FfF'ere og ikke mindst af hensyn til фkonomien. ${ }^{84}$

Håndboldspillet begyndte tilsyneladende at handle om penge, fordi der begyndte at komme prestige $\mathrm{i}$ idrætten i lokalsamfundet i løbet af 1960'erne i forbindelse med at sporten fik kulturpolitisk anerkendelse.

Perioden frem til 1970 kom til at forme sig som et kapløb mellem de to klubber om 
at nå dansktoppen først, og de lokale klubber forstod at sælge varen i en grad, så sponsorer begyndte at interessere sig for håndbold i Fredericia. Reklamer dukkede op først i kampprogrammer og siden på spillertøjet.

Klubbernes kampe fik hele »håndbold Danmarks« opmærksomhed. Pressen omdøbte Glashallen til Fredericias fæstning og lokalopgørene blev til »Slagene ved Fredericia vold«, så man kom i tvivl om, der var tale om håndbold, eller det var begivenheder i Fredericias fortidige historie, der blev refereret til.

Tilskuerne var på plads ved disse begivenheder - gerne et par timer før kampstart. De to holds tilhængere blev placeret overfor hinanden, så klubberne kunne konkurrere $\mathrm{i}$ at overdøve hinanden. Der blev på den baggrund pisket en stemning i vejret, der blev yderligere intensiveret, når aktørerne kom på banen. Spillerne begejstrede pressen, der gik helt amok. Man kunne læse om FfFs lette kavaleri, der løb om hjørner med KFUMs tunge skyts. KFUMs kanoner skød upræcist, for hver gang de lokale helte udfordrede hinanden, løb FfF af med sejren. I længden tabte det lette kavaleri dog pusten, så det tunge skyts alligevel kunne stryge til tops. I 1968 rykkede KFUMs herrer op i 1. division, mens FfF måtte blive i 2. division.

KFUMs ledere tog derefter alle midler i brug for ikke at rykke ud med det samme. Således forbød håndboldafdelingens ledere i 1968 deres herrespillere at spille fodbold i foreningen, fordi man ikke ville risikere, at de blev skadet. ${ }^{85}$

\section{Håndboldhistorier opstår}

Interessen for håndbold var på det tidspunkt blevet så stor, at der groft sagt blev talt om håndbold på alle gadehjørner i Fre- dericia. Folk begyndte ligefrem at lukke deres forretninger for at komme ud at se kampene. Når KFUMs herrer spillede, så hang der et skilt på døren ved Teaterkroen, hvor der stod: »Lukket på grund af håndbold «.

Håndbold blev en indforståethed i folks omgang med hinanden, hvad et andet eksempel kan illustrere. Da nogle bønder på Nørremarken i Fredericia i slutningen af 1960'erne skulle flyttes væk fra deres små husmandsbrug for at gøre plads til Fredericias nye håndboldhal - Glashallen var i mellemtiden blevet for lille - skulle det være foregået på følgende måde: Kommunen skulle forhandle sig til rette med hver enkelt af dem. Carl Christian Pedersen, bedre kendt som Lilleven, var en af dem. Lilleven blev kaldt ind på kommunen for at forhandle med stadsingeniør Knud Hansen og byrådsmedlem L. Bandoltz Jørgensen. Knud Hansen spurgte Lilleven, om han ikke havde en sagfører. »Nej, « svarede Lilleven, »jeg skal bare have fire kroner pr. kvadratmeter «. Der var intet andet at gøre end at forhandle. Ekspropriere kunne man ikke. »Og så vil jeg gerne forpagte jorden, indtil den skal bruges, « tilføjede Lilleven. »Hvornår bliver det? «

»Når f'erne kommer $i$ 1. division, " svarede Knud Hansen. Bandholz Jørgensen, der indtil da ikke havde sagt så meget, fik pludselig munden på gled: „Så ka' de faneme ha' den laenge! ${ }^{86}$

Det kunne Lilleven så indtil 1969. Da rykkede FfF op i 1. division og byttede plads med KFUM.

\section{Kristendommens fald}

Der var hverken tid eller plads til kristendommen i KFUMs håndboldafdeling i den atmosfære af håndbold, som gjorde sig gældende i 1960'erne. Som Dahlhus ud- 
trykker det: "Der skete et brud med kristendommen i 1960'erne, da konkurrencefokuseringen tog overhånd. ... Det førte til, at man mistede den ånd, hvor det at vare KFUM' er betød noget«.

Det forhindrede dog ikke, at der stadig fandtes ledere i KFUMs Boldklub, som hellere så spillerne i kirke end til træning om søndagen. Som Tinghus fortæller:

»Vores juniortraner havde i privat regi aftalt med sine spillere, at de skulle komme på Fredericia Stadion en søndag formiddag for at blive testet $i l \phi b \ldots$ Midt under aktiviteterne dukkede Bernhard Rasmussen fra bestyrelsen pludselig op på stadion og gjorde opmarksom på, at man krankede kirketiden."

KFUMs Boldklubs hovedbestyrelse stod i 1960'erne officielt fast på at overholde kirketidsreglen, men i virkeligheden så et flertal af lederne igennem fingre med reglen i forbindelse med den idræt, der fandt sted uden for KFUMs eget regi. Da håndboldafdelingens bestyrelse heller ikke havde moralske skrubler i den retning, lod det sig gøre for KFUMs håndboldspillere at deltage $\mathrm{i}$ de mange håndboldstævner uden for KFUM-regi, som for det meste foregik på søndage.

KFUM's Boldklubs hovedbestyrelse i Fredericia adskilte sig i deres måde at tackle forholdet på ikke fra andre KFUMklubber i Danmark. Som der står skrevet om kirketidsreglen i KFUMs Idræts For- bunds 75 års jubilæumsskrift: »At den ofte blev overtrådt, kunne ingen $i$ forbundet vare uvidende om. ${ }^{87}$ Når kirketidsreglen alligevel blev fastholdt, var det fordi, forbundet $\emptyset$ nskede at markere sin tilknytning til folkekirken. Derfor afviste forbundet også et forslag fra en række KFUM-klubber om at ophæve kirketidsreglen i 1972.

I 1977 ændrede forbundet så alligevel den beslutning. Det blev op til klubberne selv at bestemme, om de ville spille i kirketiden. ${ }^{88}$ Det ville KFUMs håndboldafdeling i Fredericia.

\section{KFUM i Fredericia nedlagges}

Nærmest som et symbol på kristendommens aflivning i KFUMs Boldklubs håndboldafdeling, så blev KFUM i Fredericia nedlagt året efter. ${ }^{89}$ Dermed var den forening $\mathrm{d} ø \mathrm{~d}$, som havde taget håndboldspillet med på sit program ca. 60 år tidligere.

Paradoksalt nok, så faldt KFUMs nedlæggelse i en tidsmæssig forstand sammen med, at håndboldafdelingen nåede toppen $\mathrm{i}$ dansk håndbold. I 1978 blev KFUMs håndboldherrer dansk mester for fjerde gang i træk.

Set i bakspejlet fik fortidens skeptikere i Indre Mission således ret, da de frygtede for, hvad sporten kunne føre til. Der var formentlig ikke én håndboldspiller i KFUMs Håndboldafdeling, der skænkede sit ophav en tanke, da den gik bort. 


\section{Litteraturliste}

B. Andersen m.fl., Håndbold i 100 år - et overblik (Nyborg, 1997).

André Brink, Sakularisering i Danmark (Århus, 1984).

Thomas U. Fenger, Sekularisering i Danmark (Århus, 1979).

Matti Goksøyr, Idrettsliv i Borgerskapets by, Norges Idrettshøgskole (Oslo, 1991).

Poul Jørgensen, Håndbold (Kbh. 1933).

Poul Jørgensen, Håndbold (Kbh. 1941).

Ove Korsgard, Kampen om Kroppen (Kbh. 1982).

P.G.Lindhart, Vaekkelse og kirkelig retninger, 3. reviderede udgave (AROS, 1978).

Else Trangbæk m.fl., Dansk Idratsliv bd.1-2 18961949 og 1940-1996 (Kbh. 1996).

Per Wind m.fl., Religionen i Krise, Berlingske studier (Århus, 1980).

Artikler og blade

Dansk Håndbold Forbund, Håndbold. Nr. 51990 (Udgiver DHF 1990).

DIF, Idratsliv nr. 2 Kbh. 1996 (Udgiver DIF 1996).

A. Pontoppidan, »Sækulariseringprocessen i Danmark « i Nyt Synspunkt nr. 111980 (Udgiver Det danske Missionsselskab 1980).

Hajo Bernett, »Die Versportlichund des Spiels«. Sportwissenschaft vol 14. nr. 2 (1984).

Fredericia Dagblad: Forskellige datoer fra periode $1940-1990$

Jyske Sport: Udg. Jyske Sports Forlag (Ålborg 1956).

Jubilæumsskrifter

Fredericia-hallen, 25 års jubilaumsskrift 1969-1994 (Fredericia, 1994).

Fredericia KFUM, 25 års jubilaumsskrift 1888-1913 (1913).

\section{Noter}

1. A. Pontoppidan, »Sækulariseringsprocessen i Danmark « I: Nyt Synspunkt, nr. 11 1980, p.10.

2. Gyldendahl og Politikens Danmarkshistorie 1850-1900, bd. 11, p. 98.

3. Bestyrelsesprotokol for KFUMs Idrætsafdeling 1916.

4. Ibid 28 april 1919.

5. KFUMs Idrætsforbund, KFUM-Idræet, 15. april 1922.

6. Ibid 15. marts 1923.
Fredericia KFUM, 50 års jubilaumsskrift 1888-1938 (Fredericia, 1938).

KFUMs Idrætsforbund, 75 års jubilaeumsskrift 19181993 (Horsens, 1993).

\section{Utrykte kilder}

Festskrift i anledning af KFUKs 10 års jubilæum i 1944.

Love og vedtægte for KFUMs Idrætsafdeling august 1916.

Love og vedtægter for KFUMs Idrætsafdeling revideret udg. 16 april 1929.

Love og vedtægter for KFUMs Boldklub 6. december 1965.

Medlemsbog for KFUK 1934-1945.

Medlemslister for KFUMs Idrætsafdeling 1925-1937.

Protokoller for KFUKs Idrætsklub 1934-1946.

Protokoller for KFUMs Idrætsafdeling 1916-1945.

Protokoller for KFUMs Boldklub 1945-1965.

Protokoller for KFUMs Håndboldafdeling 19631970.

Protokol for KFUMs Boldklubs Ungdomsafdeling 1956-1962.

Protokol for KFUMs Hovedbestyrelse 1963-1970.

Regnskabsprotokoller for Fredericia forenede Fodboldklubber 1954-1959.

Scrapbog fra Leo Ege Nielsen, Fredericiansk håndbold fra 1942 til 1972.

Interviews

Hansen, Waldemar: 16. maj 1996.

Nielsen, Leo Ege: 20. februar 1996.

Pedersen, Gyda: 23. maj 1996.

Tinghus, Erling: 30. maj 1996.

Dahlhus, Vagn Åge: 23. maj 1996.

Jensen, Peder Egon: 6. juni 1996.

7. Fredericia KFUM 50 års jubilaumsskrift 18881938 (Fredericia, 1938), p.14.

8. Love og vedtægter for Fredericia KFUMs Idrætsafdeling fra 1929.

9. Håndboldspillet er et dansk spil opfundet af Rasmus Nicolai Petersen (senere Ernst) i Nyborg i 1897.

10. KFUMs Idrætsforbund, KFUM-Idræet, 15. februar 1931.

11. Bestyrelsesprotokol for KFUMs Idrætsafdeling, d. 12. maj 1928. 
12. KFUMs Idrætsforbund, KFUM-Idrat, 15. januar 1923.

13. Det bør nævnes, at KFUMs Idrætsafdeling allerede i 1929 forsøgte at tilmelde et juniorhold i JBUs turnering, som dog aldrig kom i kamp, formentlig fordi KFUM endnu havde magt til at forhindre idrætsafdelingen $\mathrm{i}$ at bryde med KFUM-idrætten.

14. Bestyrelsesprotokol for KFUMs Idrætsafdeling d. 6. juni 1932.

15. Ibid. november 1933 (ingen datoangivelse).

16. KFUMs Idrætsforbund, KFUM-Idrat, 15. januar 1935.

17. Ibid.

18. Ibid.

19. Ibid.

20. Ibid.

21. Bestyrelsesprotokol for KFUMs Idrætsafdeling, 7. januar 1935.

22. Ibid.

23. Poul Jørgensen, Håndbold (København, 1933).

24. Festskrift i anledning af KFUKs Idrætsklubs 10 års jubilæumsfest i 1944.

25. Bestyrelsesprotokol for KFUMs Idrætsafdeling, 26. juli 1937.

26. KFUMs Idrætsforbund, KFUM-Idrat, 15. maj 1929.

27. Ibid. 15. september 1929.

28. Bestyrelseprotokol for KFUM's Idrætsafdeling, 12. oktober 1932.

29. Fredericia KFUM, 50 års jubilaumsskrift 18881938. (Fredericia, 1938)

30. Bestyrelsesprotokol for KFUMs Idrætsafdeling 25. nov. 1933. Der står, at der i forbindelse med Nielsens forslag udspandt sig en alvorlig samtale, hvori alle deltog.

31. Bestyrelsesprotokol for KFUMs Idrætsafdeling 25. nov. 1933.

32. Ibid. 29. september 1928.

33. Fredericia KFUM, 50 års jubilaumsskrift 18881938.

34. Bestyrelsesprotokol for KFUMs Idrætsafdeling 19. april 1937.

35. Ibid. 11. oktober 1937.

36. Ibid. 4. marts 1943.

37. Ibid. 23. januar 1942.

38. Pasus fra sketch opført i forbindelse med KFUKs Idrætsklubs 10 års jubilæumsfest i 1944.

39. KFUMs Idrætsafdeling skiftede i januar 1945 navn til KFUMs Boldklub uden at det berørte formålet med idræt i foreningen.

40. Bestyrelsesprotokol for KFUMs Boldklub 2. april 1946.
41. Bestyrelsesprotokol for KFUMs Idrætsafdeling 14. november 1939.

42. KFUMs Idrætsforbund, KFUM-Idrat, 15. februar 1941.

43. KFUMs Idrætsforbund, KFUM-Idrat, 15. februar 1941.

44. Bestyrelsesprotokol for KFUMs Boldklub maj 1945. (ingen datoangivelse).

45. Bestyrelsesprotokol for KFUMs Idrætafdeling 29. januar 1945.

46. Ibid. 19. april 1944.

47. Ibid. 15. juni 1943.

48. KFUMs Idrætsforbund, KFUM-Idrat, 15. februar 1948.

49. Sekularisering betyder også verdsliggørelse. André Brink har i bogen »Sækularisering i Danmark« defineret sekularisering som en proces, hvor sammenhængen mellem individets hverdagsliv og den religiøse dimension som livstydning formindskes. Se Brink p. 223 for mere.

50. UAere og YAere er definitioner på det civile KFUMs unge medlemmer (UA) og yngre drenge (YA).

51. Bestyrelsesprotokol for KFUMs Boldklub 28. januar 1952.

52. Ibid. 11. august og 3. november 1952.

53. HA er betegnelsen for de voksne medlemmer i KFUM.

54. KFUMs Boldklubs protokol, 9. februar 1953.

55. Ibid. 4. oktober 1954.

56. Ibid. januar 1955 (ingen datoangivelse).

57. KFUMs Idrætsforbund, KFUM-idrat, 15. januar 1951.

58. Waldemar Hansen var medlem af Nørremarkens Håndbold Klub, som holdt til på Nørremarken i Fredericia og kendte Johs. Rasmussen fra dennes virksomhed som folkeskolelærer på Nørremarken. Hansen fortæller, at Rasmussen så Nørremarkens håndboldkampe, og at det var $\mathrm{i}$ den forbindelse at omtalte episode fandt sted.

59. Interview med Waldemar Hansen 16. maj 1996.

60. Interview med Vagn Åge Dahlhus 30. maj 1996. Dahlhus kom med i KFUMs Boldklubs bestyrelse i 1952 og er stadig medlem.

61. Interview med Gyda Pedersen 23. maj 1996.

62. Interview med Vagn Åge Dahlhus 30. maj 1996.

63. Ibid.

64. Ibid.

65. Bestyrelsesprotokol for KFUMs Boldklub 4. marts 1952.

66. Dansk Idræts Forbund, Idratsliv nr. 2 1996. E. Trangbæk »Fra folkeforlystelse til folkebevægel- 
se« I: Dansk Idratsliv 1940-1996, bd. 2 (Kbh. 1996), p. 24.

67. I 1953 tilmeldte klubben 3 hold til KFUMs landsmesterskaber, og i 1958 blev 17 hold tilmeldt.

68. Nøjagtig som KFUM oplevede FfF en eksplosiv tilgang af håndboldspillere. FfF blev stiftet i 1953, og efter kun fem år kunne klubben præstere 250 håndboldspillere.

69. Fredericia Dagblad, 22. februar 1954.

70. Jyske Tidende februar 1956. Foromtale til kamp, 26 , februar 1956. Det bragte citat foreligger som et udklip fra en scrapbog og kan ikke datobestemmes.

71. Jyske Sport december 1956, 24.

72. Ordret citeret fra klubbens protokol.

73. Bestyrelsesprotokol for KFUMs Boldklub, december 1957.

74. KFUMs Idrætsforbund, KFUM-Idrat, 15. september 1963.

75. Love og vedtægter for KFUM og Ks Idrætsforbund. Bragt i KFUM-Idrat, 15. maj 1963.

76. KFUM og Ks Idrætsforbund, KFUM-idrat 15. juni 1962 .
77. Bestyrelsesprotokol for KFUMs Boldklub, 13. august 1962.

78. Love og vedtægter for Fredericia KFUMs Boldklub, 6 december 1965.

79. Den oplysning bygger på et interview med Peder Egon Jensen, 6. juni 1996.

80. Interview med Erling Tinghus, 23. maj 1996.

81. Med sportificering menes en proces i retning af præstation, konkurrence og resultatorientering.

82. Bestyrelsesprotokol for KFUMs Boldklubs hovedbestyrelse, 13 august 1962.

83. Ibid., 28 januar 1963.

84. Fredericia Dagblad, 16. marts 1965.

85. Bestyrelsesprotokol for KFUMs håndboldafdeling, 28. august 1968.

86. 25 års jubilæumsskrift for Fredericiahallen 19691994 (Fredericia, 1994), p. 51.

87. KFUMs Idrætsforbund, 75 års jubilaumsskrift 1918-1993 (Horsens, 1993), p. 23.

88. Ibid.

89. Bestyrelsesprotokol for KFUMs hovedbestyrelse, 8. maj 1978. 